\title{
Labour Market and Educational Services Trends in Post- Conflict Territories of Ukraine
}

\author{
By Tetiana Hudima ${ }^{1}$, Volodymyr Ustymenko ${ }^{2}$, Ruslan Dzhabrailov ${ }^{3}$, \\ Vitalii Oliukha ${ }^{4}$, Oleksandr Illarionov ${ }^{5}$
}

\begin{abstract}
Promotion of youth employment, especially in the post-conflict territories of Donetsk and Luhansk regions of Ukraine, is one of the key global problems of a country that is a challenge to its sustainable development. Higher education institutions play an important role in this process. They form the labour potential for the development of a region. However, their activities do not always correspond to their (regional) needs. Studies on employment experience and labour mobility of graduates of higher education establishments in Donetsk and Luhansk regions of Ukraine evidence of the extremely high rate of re-profiling of young graduates and / or their migration to other regions of the country or abroad. This article proposes a number of measures, including within the framework of educational reform, to be implemented to reduce youth unemployment both in the region and in Ukraine as a whole. It is noted that it is advisable to intensify the processes of supporting the initiatives of young people in post-graduate vocational training and employment, encouraging them to actively seek employment and to acquire a profession or occupation in demand in the labour market. Attention is drawn to the need for awareness-raising and education in this regard. It is argued that measures aimed at preventing the migration of scientists should be included in national policy documents. It is suggested that special attention be given to the programme approach, which should form the basis of a legal mechanism to promote the preservation of the region's intellectual potential.
\end{abstract}

Keywords: sustainable development, promotion of youth employment, post-conflict territories, higher education institutions, migration, labour market, programme approach

\section{Introduction}

The issue of youth employment in the Donetsk and Luhansk regions is a key to the economic development of the region, especially in the context of the military conflict. Institutions of higher education play an important role in this process. They form the labour potential, preparing a skilled workforce, which in future will create a social product, provide opportunities for scientific and technological development of the region. The

\footnotetext{
| ${ }^{1}$ Doctor of Law, Deputy Head of Department, State organization 'V Mamutov Institute of Economic and Legal Research of the National Academy of Sciences of Ukraine'

${ }^{2}$ Corresponding Member of the National Academy of Sciences of Ukraine, Doctor of Law, Professor, Director, State organization $\mathrm{V}$ Mamutov Institute of Economic and Legal Research of the National Academy of Sciences of Ukraine'

${ }^{3}$ Doctor of Law, Deputy director, State organization 'V Mamutov Institute of Economic and Legal Research of the National Academy of Sciences of Ukraine'

${ }^{4}$ Doctor of Law, Docent, Lead Researcher, State organization 'V Mamutov Institute of Economic and Legal Research of the National Academy of Sciences of Ukraine'

${ }^{5}$ Senior Researcher, State organization 'V Mamutov Institute of Economic and Legal Research of the National Academy of Sciences of Ukraine'
} 
opposite is true today. The imbalance between the educational services market and the labour market in Donetsk and Luhansk regions, manifested in the dominance of supply over demand, the excess of demand for certain specialties and the absence of demand for others, negatively affect on the economic situation of these regions and the level of economic security of higher educational establishments is reduced.

As a result, a large proportion of the specialists who receive higher education do not find employment in a specialty and migrate to other regions of Ukraine and abroad.

The purpose of the research is to analyse current trends in the development of labour markets and educational services in Donetsk and Luhansk regions; to identify the causes of imbalances in their interaction and to develop proposals for their elimination ${ }^{1}$.

\section{Literature Review}

The conceptual design of the research was preceded by an introduction to the fundamental and applied works: Abkhezr, P., McMahon, M., \& Rossouw (Abkhezr, P., McMahon, M., \& Rossouw, P. (2015), P. Bezanson, L., Hopkins, S., \& Neault, R.A. (Bezanson, L., Hopkins, S., \& Neault, R.A. (2016), Caliendo, M., \& Schmidl, R. (Caliendo, M., \& Schmidl, R. (2016), Hardgrove, A., Rootham, E., \& McDowell, L. (Hardgrove, A., Rootham, E., \& McDowell, L. (2015). The authors studied youth unemployment, labour market public policies and the role of career counsellors in Australia, Canada, Europe, Great Britain. However, research doesn't take into account the specificities of the development of higher education institutions and the education and employment of youth on conflict and post-conflict territories.

There are many case research on the role of education, emotional intelligence and parents in orienting youth to the labour market (Câmpeanu-Sonea, E., Sonea, A., \& Brefelean, V.P. (2013); Fabio, A., \& Kenny, M.E. (2015); Fabio, A., \& Kenny, M.E. (2015); Leenders, M.V.E., Buunk, A.P., \& Henkens, K. (2017). Scientific proposals can be useful in solving the problem of youth employment in Donetsk and Luhansk regions.

Quite interesting is the scientific work of the team of authors Assemgul A. Moldazhanova, Gulzhanar K. Dzhumazhanova, Aizhus K. Kokoraeva on the topic «Improving the Mechanism of Youth Employment in the Commonwealth of Independent States in the Global Context», in which scientists have devoted attention to searching for ways of improving the process of youth employment. The scientific work includes a survey of senior-level students specializing in various fields and institutions of higher education in the countries of the Commonwealth of Independent States, in particular the Republic of Armenia, Azerbaijan, the Republic of Belarus and the Republic of Kazakhstan, Kyrgyz Republic, Republic of Moldova, etc. As we see, this approach (survey) is an important source of information and will be used in this research (Assemgul A. Moldazhanova, Gulzhanar K. Dzhumazhanova, Aizhus K. Kokoraeva (2019).

The economic security of regions, as well as the interaction of labour markets and educational services, have been reflected in the scientific works of scientists such as: M. P.

1 At the end of 2018, the quantitative and qualitative research aimed at the defining key problems and perspectives of Donbas labor market was conducted under the sponsorship of Czech organization 'People in Need' - 'Evaluation of Donbas Universities Economic Potential'. The authors of the article were also involved into the mentioned survey. 
Denisenko, S. V. Breus (Denysenko, M. P. \& Breus, S. V. (2016), H. V. Kozachenko, Y. S. Pogorelov, H. D. Tyulyenyev (Kozachenko, H. V., Pohorelov, Yu. S. \& Tiulieniev, H. D. (2015), T. L. Shestakovs'ka (Shestakovska, T. L. (2015), L. P. Snihyr (Snihyr, L. P. (2015), A. P. Hirman, D. O. Zemlyanyy, K. S. Hnatchenko (Hyrman, A. P., Zemlianoi, D. A. \& Hnatchenko, K. S. (2016), D. YU. Bottayeva (Bottaeva, D. Yu. (2017), O. V. Martyakova, O. V. Mudra (Martiakova, O. V. \& Mudra, O. V. (2013), I. A. Lybak (Lybak, I. A. (2012) and other. Despite the series of research, modern trends in the development of labour markets and educational services in Donetsk and Luhansk oblasts remain insufficiently researched. For the most part, the above-mentioned studies do not use qualitative or quantitative indicators and focus on a different region or time period.

\section{Methodology and Research Methods}

Statistical and sociological research methods were used to achieve this objective. The statistical research assessed the level of development of the region's labour market, its current level of burden and the structure of supply and demand. In addition, the statistical research included an assessment of the level of development of the educational services market of the region, an assessment of the structure of training and rankings of Donetsk and Luhansk regions universities. The sociological research included the collection of quantitative and qualitative indicators, by means of a survey of focus groups among undergraduate students of various specialities, teachers of higher educational establishments and employers of Luhansk and Donetsk regions.

\section{Results}

One of the reasons for the unbalanced development of the region's labour market is the lack of willingness of young people to enter professions that are in demand among employers. Today's young people, in their choice of professions, do not, in most cases, focus on the current demand for a given profession, focusing on the possibility of financial well-being after obtaining a job. However, owing to their low level of labour market awareness, young people are wrong to think that a profession would pay them decent wages.

According to a survey of students (graduates), most of them, when choosing their profession, were oriented towards the possibility of earning a decent wage in the future (51,6 per cent). On the positive side, almost half of those surveyed weigh the prospects for future employment. The ambition and future orientation of young people confirm the assessment of the possibility of career advancement with professional self-determination (40,3 per cent prioritize this criterion). Only 7,3 per cent of students are abroad-oriented in their choice of profession, indicating the positive intentions of young people and the possibilities available for their retention in the region, while creating favourable conditions for self-development and realization. 


\section{What was important for you when choosing a future profession?}

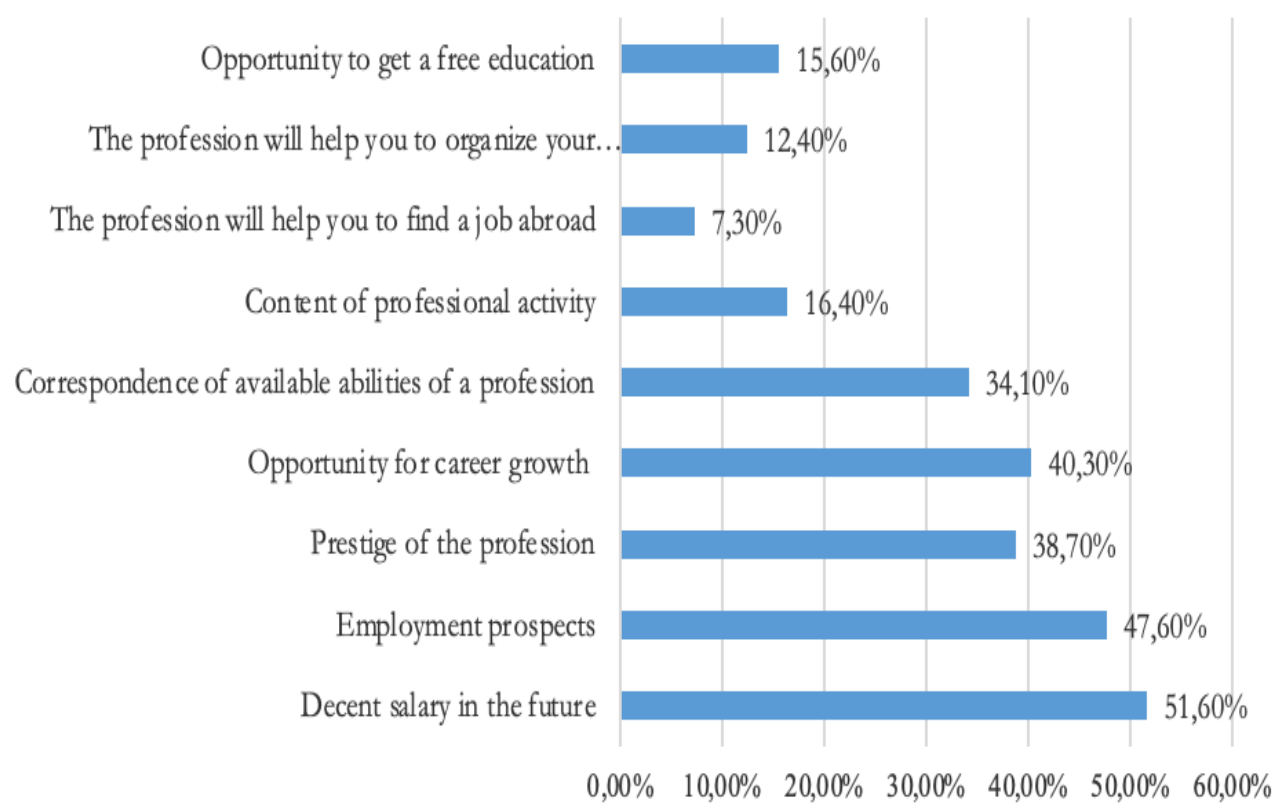

Figure 1. Youth priorities in career choices

Today's young people have a fairly high level of independence and are mostly guided by their own opinions in determining their career path (about 70 per cent). 16,4 per cent of students rely on their parents' opinions when choosing a profession, while 7,3 per cent rely on representatives of institutions providing vocational guidance services.

The results show that it is necessary to focus specifically on activities to attract and inform young people, to conduct programmes of professional self-determination and to popularize certain professions.

The results of the survey on the evaluation of the demand for a profession received by students confirm the insufficient level of provision of professional information in the region. Most of them, 71,38 per cent, believe that their profession is very much in demand in the labour market, although most of them study in occupations that are otherwise redundant in the region's labour market. This misconception is linked to a lack of understanding among young people of the processes of work and the actual state of the labour market, as well as the available employment prospects. Previous statement is confirmed by $11 \%$ of respondents' replies. They found it difficult to answer this question and therefore their level of awareness was rather low (Figure 2). 


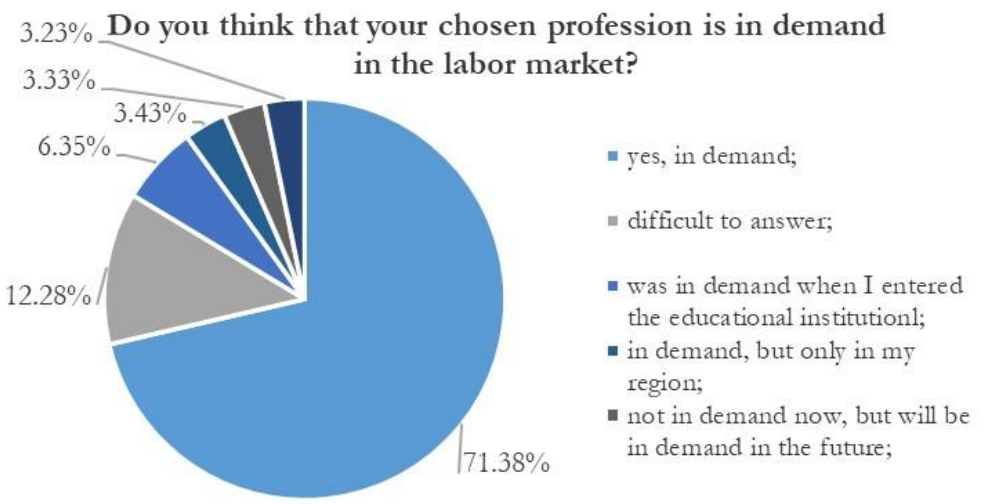

Figure 2. Students' perception of the level of demand for the profession in the labour market

In view of the above, it may be concluded that there are gaps in the current system of vocational guidance for the population of the region. The introduction of a set of measures to diagnose young people's professional identification and awareness of the world of occupations and their demand will help to bring the labour market into a more balanced state by adjusting and building vocational skills educational trajectories for youth.

To some extent, the imbalance between the demand for and supply of human resources in the labour market is related to the lack of effective interaction between the activities of higher education institutions and the needs of the real economy. Today business is one of the most important and real customers for specialists. In the context of the shortage of qualified personnel, including in specialized fields of knowledge, business is beginning to actively fill the gap of knowledge with «own efforts» or through new forms of additional education - second higher education, courses of further qualification, seminars, business schools and the like. These forms of education are much more oriented towards the needs of modern society and the emergence of new industries than the traditional five-year education. Therefore, the work of developing the student population and preserving the intellectual potential should begin with the establishment of close cooperation between higher education institutions and employers in the region.

The orientation of modern education in the region towards the training of personnel in humanities, including legal, social, economic and administrative professions, has led to an acute shortage of personnel in engineering, construction, trades, etc. (table 1).

Table 1: Disparities in the labour market and the market of educational services

\begin{tabular}{|l|l|l|}
\hline Disproportion & Problem description & Reasons \\
\hline $\begin{array}{l}\text { The gap between } \\
\text { supply and demand for } \\
\text { skilled workers in } \\
\text { quantitative and } \\
\text { qualitative terms }\end{array}$ & $\begin{array}{l}\text { Insufficient supply of } \\
\text { construction workers, } \\
\text { drivers of vehicles and } \\
\text { installations, housing and } \\
\text { communal services workers, } \\
\text { light industry workers }\end{array}$ & $\begin{array}{l}\text { In the structure of the region's economy, } \\
\text { the predominant positions are occupied by } \\
\text { the fields of mechanical engineering, } \\
\text { chemical and coal industries, and electric } \\
\text { power. } \\
\text { The promotion of higher education upsets } \\
\text { the balance of training of specialists at } \\
\text { different levels of education. }\end{array}$ \\
\hline
\end{tabular}




\begin{tabular}{|l|l|l|}
\hline Disproportion & Problem description & Reasons \\
\hline $\begin{array}{l}\text { The gap between } \\
\text { agricultural specialists }\end{array}$ & $\begin{array}{l}\text { Insufficient supply of } \\
\text { zootechnicians, agronomists, } \\
\text { machine operators, livestock } \\
\text { breeders }\end{array}$ & $\begin{array}{l}\text { Underdevelopment of the socio-cultural } \\
\text { sphere in the countryside, low wages }\end{array}$ \\
\hline $\begin{array}{l}\text { Surplus of financial, } \\
\text { economic and legal } \\
\text { specialists }\end{array}$ & $\begin{array}{l}\text { Insufficient demand for } \\
\text { accountants, financiers, } \\
\text { economists, lawyers }\end{array}$ & $\begin{array}{l}\text { Retraining of specialists with higher } \\
\text { professional education. } \\
\text { The customer of higher education services } \\
\text { is the population that does not take into } \\
\text { account the regional demand for specialists }\end{array}$ \\
\hline Youth unemployment & $\begin{array}{l}\text { The labour market needs } \\
\text { specialists with work } \\
\text { experience }\end{array}$ & $\begin{array}{l}\text { Low competitiveness of freelance } \\
\text { graduates; lack of information about } \\
\text { market needs at the time of admission to } \\
\text { universities and about real employment } \\
\text { opportunities; the labour market is } \\
\text { characterized by an oversupply of highly } \\
\text { qualified specialists }\end{array}$ \\
\hline $\begin{array}{l}\text { Increased demographic } \\
\text { burden on the working } \\
\text { population }\end{array}$ & $\begin{array}{l}\text { Dynamics of the ratio of } \\
\text { able-bodied and } \\
\text { incapacitated population } \\
\text { quantitative filling of imbalance (attraction } \\
\text { of migrants) - qualitative discrepancy of } \\
\text { levels of education }\end{array}$ \\
\hline Rural unemployment & $\begin{array}{l}\text { Territorial mismatch of the } \\
\text { volume of vacancies supply } \\
\text { of labour }\end{array}$ & $\begin{array}{l}\text { Underdeveloped socio-cultural sphere and } \\
\text { infrastructure in rural areas }\end{array}$ \\
\hline
\end{tabular}

The lack of quality education and suitable work (with competitive pay and working conditions, etc.) is a catalyst for the migration of young people (in particular students and young scientists) to seek education / work abroad.

The proximity to the zone of military conflict further intensify the above-mentioned process.

According to UNESCO data, a significant - almost twofold - increase in the number of Ukrainian students abroad occurred after 2013 and reached its peak in 2015 (68,2 thousand people). As of 2016, the number of Ukrainian students abroad has slightly decreased, but this may be due to incomplete data (Figure 3).

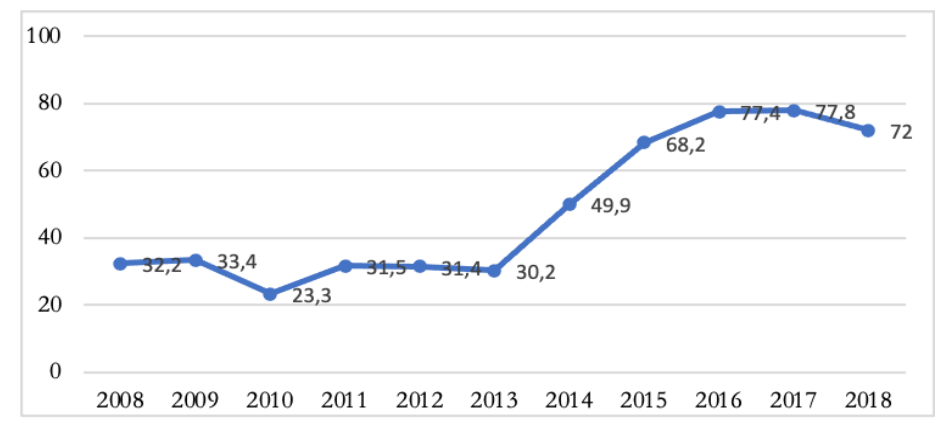

Figure 3. Number of Ukrainian students abroad (thousands of people), 2008-2018.

Source: according to UNESCO. Outbound internationally mobile students by host region: bttp:/ / data.uis.unesco.org/Index.aspx?queryid=171\#' 
It should be noted that there are no statistics on citizens studying abroad in Ukraine, nor information on how many of them return to their homeland after completing their studies. In focus groups for displaced university students, almost half of the respondents indicated a desire to study and work abroad. Young people in Luhansk and Donetsk regions consider educational migration mainly as a way of emigration, a sort of social elevator, allows to enter the labour market of EU countries.

Foreign higher education institutions and intermediary firms in the region actively promote education abroad in schools, public transport and education exhibitions. To this is added the general belief in a better life abroad. As a result, a foreign education becomes something desirable, despite the advantages and disadvantages associated with it.

Until 2014, the Russian Federation had been a leader among the countries that accepted students from Ukraine. It is understandable that with the beginning of the armed conflict there was a reorientation, and Poland came first place (26,800 students), Germany (6,400 students) second, and Czechia (3,200 students) third. There is no clear information regarding Russia today (UNESCO (2021)).

Statistics on Ukrainian citizens studying at postgraduate level abroad (PhD programs) are limited. According to CEDOS, the number of Ukrainian $\mathrm{PhD}$ students in the academic year 2015/2016 was 1,600. The main countries that have awarded degrees for Ukrainians were Germany (525), Poland (380), Czech Republic (223), France (201), Switzerland (105). However, amount of $\mathrm{PhD}$ students in the United States, the United Kingdom, and Canada remained unknown due to paid access to information (Stadnyy, YE.V. (2017)).

The issue of the leaving of Ukrainian youth to study abroad has just begun to receive attention in Ukraine. There is a lack of qualitative research and statistics in this area.

It is already clear, however, that the lack of jobs and decent wages contributes to the outflow of young people and to the search for employment abroad. That is why strategic education policies should provide jobs for young professionals, in accordance with their level of training and taking into account the possibilities of the national economy. However, the prioritization of the role of labour market demand in achieving this goal is not unconditional. Achieving market equilibrium is possible in an ideal market economy. In reality, there are various exceptional factors that make adjustments and must be taken into account.

Thus, the relative surplus of specialists with higher education in the labour market, in terms of objective economic laws, requires a reduction in the number of universities, the recruitment of students and the cost of education. However, a sociocultural analysis of the problem shows that such actions will reduce the intellectual potential of society, negatively affect its quality, act as a deterrent to economic growth and, finally, it will run counter to the objective processes of social progress - the formation of the information society and the knowledge economy. In view of the above, it is necessary not to reduce but to reorient the development of higher education, to establish mechanisms for harmonizing the supply of educational services and the needs of the labour market, and to engage in strategic planning for the development of this sphere.

The labour market, in particular in Donetsk and Luhansk regions, formulates modern requirements for the market of educational services, so the effectiveness of educational policies should be measured by indicators of the quality of education, its accessibility and its relevance to the needs of the labour market. The urgency of the problem becomes even 
more evident in the context of the expansion of fee-paying education.

While analysing these problems, it is important to bear in mind that the structure of the modern labour market is composed of permanent and variable determinants. Permanent determinants are relatively stable, difficult to predict, and supply of these determinants tends to exceed demand, ensuring that jobs compete and employers can choose.

These include occupations related to the development of the most important industries of any country and are therefore in steady demand in the labour market.

Temporary determinants are characterized by a surge in demand and an equally rapid decline after supply is satisfied.

The problem of disequilibrium in the labour market in the region is exacerbated by the low level of awareness among young people of the state and dynamics of demand for specific occupations, and by the formation of public opinion on the prestige or lack of prestige of professions, and, most often, temporary advantages in choosing a profession. Thus, many jobs are offered to young people, but there are no objective criteria (or information access) to assess the future effectiveness of today's professional choices. This in turn exacerbates the problem of investing in human capital.

Looking at the experience of Western countries, in the most developed countries, much attention is paid to forecasting the dynamics of the labour market. In the United States in particular, such forecasts are developed at both the federal and state levels and are available to any interested person.

At the international level, labour market forecasting is carried out by:

- The Bureau of Labour Statistics (U.S. Bureau of Labour Statistics), which maintains regular statistics on the labour market and produces projections every two years for occupations and branches of the economy;

- Ministry of Education;

- The National Science Foundation (NSF) is a centre for studying the problems of personnel support for scientific research activities in the country; it monitors the professional development of personnel, starting with students in senior classes, students, postgraduate students, doctoral students and, Finally, university graduates of various levels of qualification (bachelor, master or doctor).

The statistical data and analytical reports of these institutions contain the most reliable information that makes it possible to predict the dynamics of the labour market using mathematical and probability tools.

Of course, such forecasts are not always accurate, given the specificities of dynamic and action-prone factors - from global to regional and local - to the labour market. For example, the extent and consequences of the end of the conflict in eastern Ukraine are unlikely to be foreseen and reflected in such projections.

At the same time, the increase in private investment in higher education, the increase in the proportion of students receiving tuition on a fee-paying basis, and the increase in public spending on acquiring additional qualifications are raising the question of the costeffectiveness of this investment.

The growing interest in higher vocational education services without taking into account the needs of the labour market is due to the social value of higher education as a factor of the stable social position of the individual in society.

The lack of confidence in young people's employment prospects leads to the reproduction 
of the latest non-standard strategies to be distinguished from the general population. For example, one of the popular strategies of «mass individualization» is to combine university studies with work.

Research on the employment experience and labour mobility of university graduates in the region shows a very high level of mass conversion of young graduates.

The prospects for the progressive development of modern society are determined primarily by the accessibility of postgraduate vocational education. It is no accident that such education programmes are being introduced in many countries of the world - the United States, France, Germany, the United Kingdom, Japan and others.

Consequently, in the current context, there is a need to step up the processes of supporting youth initiatives for postgraduate vocational training and employment, encouraging them to actively seek employment and acquire a profession or profession, in demand in the labour market. To that end, comprehensive and well-qualified information on the career prospects of young people is essential.

The main measures to be taken to reduce youth unemployment, both in the region and in Ukraine as a whole, should be advocacy and education. This requires to:

establish Youth Centres / Labour Offices (like international experience);

introduce projects aimed at financing measures to promote youth employment in the region;

carry out on an ongoing basis (at least once a year) an analysis of the specialities, skills and qualifications of graduates;

include compulsory student internships in the curricula;

introduce a mechanism to encourage students to work part-time in their free time and to set up pilot enterprises in universities;

develop and implement a mechanism for financial and other support to enterprises, institutions and organizations in the region involved in providing internships for students as well as job placement, including job placements;

provide training in job-seeking techniques, job opportunities and the strengthening of their own efforts to solve employment problems and increase their self-esteem;

disseminate materials on: employment problems; the state of the regional labour market; and potential employers, with a view to creating conditions for personal selfdetermination;

organize meetings with employers and former unemployed persons who have successfully found a job or started their own business. Ensure that positive experiences are widely publicized by the media;

introduce courses in job-seeking techniques and optional courses in self-employment; coordination of international activities: exchange of students for internships, volunteer work and temporary work (Turchak, V.V., Vashchenko, T.A. (2010));

introduce self-employment programmes for young people, in particular the allocation of a budget for setting up a business with legal support in the first year of starting a business (example: pilot project on the employment of members of poor families and internally displaced persons (KMU of Ukraine Resolution 1154 of 2 December 2015);

organise trainings on business management (step-by-step coaching), peculiarities of franchising etc.

The main actions to be taken in the reform of the education system should be: 
establishment of an efficient and effective system of lifelong learning;

introduction of a discipline taught by a psychologist practising in all educational establishments. The purpose of this discipline should be to instil in young people a positive motivational attitude towards work, self-confidence, etc.;

to establish in all educational institutions units for the employment of graduates (Career Centres);

forecasting the amount of vocational training for young people in educational establishments of various types, taking into account the demand in the labour market. Increase of State contracts and scholarships of the Ministry of Education and Science of Ukraine for specialties that are in demand according to the region. It is precisely the formation of a State order for the training of specialists in the relevant field for the regions that has been recognized as one of the objectives of the 2021-2023 plan of action for the implementation of the 2021 State Strategy for Regional Development 2027, approved by Order of the Cabinet of Ministers of 12 May 2021,497-r;

improving access to postgraduate education.

In addition, it would be useful to draw attention to the current problem of the migration of scientists/teachers in Donbas. It should be noted that such migration is a general problem in Ukraine, since, for the most part, scholars move outside the country rather than within the country.

In many countries where science has been negatively affected by the migration of scientists, many measures are being introduced to encourage their return. It should be noted that domestic legislation does not pay due attention to this. Nor does the Strategy 2025 contain any measures aimed at preventing the migration of scientists. However, despite the negative effects of this process, in particular the decline in the country's innovative capacity, it would be advisable to create the conditions for an improvement in this area (Ustimenko, V.A., Dzhabrailov, R.A., Hudima, T.S. (2018).

\section{Conclusions}

To conclude this analysis, Ukraine is gradually moving towards solving the problems of preserving the intellectual potential of the population and preventing migration. Of course, such actions need to be improved, taking into account the proposals and data presented in the study. It is suggested that particular attention be paid to the programmatic approach in addressing a number of migration policy issues. In particular, in the regions of Luhansk and Donetsk, which are the regions most affected by labour and intellectual migration, it would be advisable to develop programmes to facilitate the return and reintegration of migrants. It is the programmatic approach that should form the basis of a legal framework to promote the preservation of the region's intellectual potential.

\section{Acknowledgements}

This work would be impossible without the financial support of the Czech nongovernmental 'People in Need'. The article was prepared as part of a scientific studies on 'Evaluation of Donbas Universities Economic Potential'. 


\section{References}

CISID (2018). Evaluation of Donbas Universities Economic Potential. A summary of the project. Available at: http://cisid. org.ua/analitychna-robota/

Abkhezr, P., McMahon, M., \& Rossouw, P. (2015). Youth with refugee backgrounds in Australia: Contextual and practical considerations for career counselors. Australian Journal of Career Development, 24(2), 71-80.

Bezanson, L., Hopkins, S., \& Neault, R.A. (2016). Career guidance and counselling in Canada: Still changing after all

Caliendo, M., \& Schmidl, R. (2016). Youth unemployment and active labor market policies in Europe. IZA Journal of Labor Policy, 5(1), 1-30.

Hardgrove, A., Rootham, E., \& McDowell, L. (2015). Possible selves in a precarious labour market: Youth, imagined futures, and transitions to work in the UK. Geoforum, 60, 163-171.

Câmpeanu-Sonea, E., Sonea, A., \& Brefelean, V.P. (2013). The role of emotional intelligence in labour market orientation and career development. Management Dynamics in the Knowledge Economy, 1(1), 127-142.

Fabio, A., \& Kenny, M.E. (2015). The contributions of emotional intelligence and social support for adaptive career progress among Italian youth. Journal of Career Development, 42(1), 48-59.

Samo, P. (2014). The role of higher education in supporting graduates' early labour market careers. International Journal of Manpower, 35(4), 576-590.

Leenders, M.V.E., Buunk, A.P., \& Henkens, K. (2017). The role of the relationship with parents with respect to work orientation and work ethic. The Journal of General Psychology, 144(1), 16-34.

Assemgul A. Moldazhanova, Gulzhanar K. Dzhumazhanova, Aizhus K. Kokoraeva (2019). Improving the Mechanism of Youth Employment in the Commonwealth of Independent States in the Global Context. Journal of Entrepreneurship Education, Vol. 22, Issue 1.

Denysenko, M. P. \& Breus, S. V. (2016). Vplyv elementiv rynku pratsi na zabezpechennia ekonomichnoi bezpeky vyshchykh navchalnykh zakladiv. Upravlinska, finansova ta marketynhova diialnist pidpryiemstv v umovakh nestiikoi ekonomiky monohrafiia; za red. K. F. Kovalchuka, Porohy, Dnipropetrovsk, 432-439 [in Ukrainian]

Kozachenko, H. V., Pohorelov, Yu. S. \& Tiulieniev, H. D. (2015). Ekonomichna bezpeka vyshchoho navchalnoho zakladu: pidhruntia zabezpechennia. Finansovo-ekonomichna bezpeka: stratehichna analityka ta audytorskyi suprovid: monohrafiia, KhNUMH im. O. M. Beketova, Kharkiv, 110-130 [in Ukrainian]

Shestakovska, T. L. (2015). Rehuliuvannia vzaiemodii rynkiv pratsi ta osvitnikh posluh yak shliakh zmitsnennia ekonomichnoi bezpeky systemy osvity, Investytsii: praktyka ta dosvid, № 5, 42-46 [in Ukrainian]

Snihyr, L. P. (2015). Konkurentospromozhnist vyshchykh navchalnykh zakladiv yak mekhanizm zabezpechennia ekonomichnoi bezpeky osvity, Visnyk Khmelnytskoho natsionalnoho universytetu, №. 4, T. 2, 157-162 [in Ukrainian]

Hyrman, A. P., Zemlianoi, D. A. \& Hnatchenko, K. S. (2016). Analiz rynka obrazovatelnykh uslug Ukrainy v kontekste sotsialno-ekonomicheskoy bezopasnosti, Biznes Inform, №. 6, 113-118 [in Russian]

Bottaeva, D. Yu. (2017). Osobennosti vzaimodeystviya rynka truda i rynka obrazovatelnykh uslug, Vestnik universiteta, № 3, 215-219 [in Russian]

Martiakova, O. V. \& Mudra, O. V. (2013). Suchasni modeli harmonizatsii rynkiv osvitnikh posluh ta pratsi, Visnyk sotsialno-ekonomichnykh doslidzhen, Vyp. 4 (51), 274-281 [in Ukrainian]

Lybak, I. A. (2012). Rynok osvitnikh posluh i konkurentospromozhnist navchalnykh zakladiv, Visnyk Khmelnytskoho natsionalnoho universytetu, № 2, T. 1, 192-196 [in Ukrainian]

Ustimenko, V.A., Dzhabrailov, R.A., Hudima, T.S. (2018). Economic efficiency vs social justice: priorities of the formation of Ukraine's migration policy. Visnyk Pivdennoho rehional'noho tsentru Natsional'noyi akademiyi pravovykh nauk Ukrayiny № 16, 37-45. [in Ukrainian]

U.S. (2021) Bureau of Labour Statistics. Available at: https://www.bls.gov

NCF (2021). National Science Foundation. Available at: https://www.nsf.gov

Stadnyy, YE.V. (2017). Ukrayins'ki studenty za kordonom: fakty ta stereotypy. CEDOS. 2017. Available at: https://cedos.org.ua/uk/articles/ukrainski-studenty-za-kordonom-fakty-ta-stereotypy. [in Ukrainian]

UNESCO (2021). Outbound Internationally Mobile Students by host region. UNESCO. http://data.uis.unesco.org/Index.aspx?queryid=171\#

Turchak, V.V., Vashchenko, T.A. (2010). Pratsevlashtuvannya molodi v Ukrayini: problemy ta shlyakhy yikh vyrishennya. Available at: http://www.rusnauka.com/35 OINBG_2010/Economics/73863.doc.htm [in Ukrainian] 